\title{
Kesiapan Penerimaan Kepala Sekolah terhadap Teknologi Google Docs: Studi Kasus Pelatihan Calon Kepala Sekolah Dasar Kabupaten Ngawi
}

\author{
S.T. Nurjaningsih ${ }^{8}$ \\ nurjaningsih@student.uns.ac.id
}

\begin{abstract}
One of the technology-based applications cloud computing introduced to the participants of primary school principals education training is theapplication Google Docs. Use ofapp technology Google Docs or known Google Docs is causing a reaction on the user himself, namely in the form of acceptance and rejection. The acceptance of a technology is strongly influenced by the readiness of the users of the technology. This study aims to examine whether the participants of the candidate head sekolaj SD Kabupaten Ngawi already have the readiness and acceptapplication technology Google Docs for individual task completion when On-The-Job Learning in school alone and a second internship. The model used to describe the relationship that factors affect the readiness and usage of theapplication Google Docs is the Technology Readness Index (TRI) on Technology Acceptance Model (TAM) by the method research using factor analysis on SPSS software version 18.0. The result variable self-ability to computer and variable of readiness that is optimistic, and innovation have an effect on signifikan to variable of acceptance.
\end{abstract}

Keywords: Google Docs, TAM, TRI, SEM. 


\section{PENDAHULUAN}

S

alah satu kursus persiapan yang harus dijalani calon Kepala Sekolah adalah On The Job Learning (OJL) selama 200 jam belajar dalam bentuk pembelajaran untuk mempraktikkan kepemimpinan, materi supervise, manajerial dan akademik yang diperoleh selama tatap muka dalam fase In Service Learning 1 selama 70 jam belajar. Kegiatan ini membutuhkan laporan kinerja yang akan disajikan pada tahap in service Learning tahap 2. Calon kepala sekolah Kabupaten Ngawi yang ikut serta dalam kegiatan ini terdiri dari 15 kecamatan yang tersebar. Oleh karenanya forum komunikasi atau diskusi selama kegiatan OJL sangat efektif ketika memanfaatkan aplikasi teknologi informasi sekaligus mempersiapkan mereka untuk menjadi pemimpin pembelajaran yang inovatif.

Pengenalan teknologi cloud computing melalui pengenalan aplikasi generasi cloud computing seperti Google Documents telah menjadi salah satu bagian dari kurikulum mata pelajaran Teknologi Informasi dan Komunikasi (TIK) yang dialokasikan 2 jam pengajaran dalam pelatihan In Service Learning 1. Melalui aplikasi ini, diskusi dan pertukarab ide antar sesama peserta pelatihan untuk mendukung keberhasilan lulusan sangat dimungkinkan. Selain itu, salah satu yang mendukung pembelajaran dengan memanfaatkan teknologi ini adalah fakta bahwa beberapa sekolah mereka mendapatkan fasilitas Wi-Fi dari dinas pendidikan. Para peserta pelatihan di LPPKS tersebut memiliki laptop dan smartphone yang sangat mendukung komunikasi meskipun pemanfaatanya secara optimal masih terkendala. Kesiapan pengguna dan penerimaan penggunaan aplikasi generasi cloud computing seperti Google Documents akan terlihat ketika pengguna mulai belajar menggunakan teknologi tersebut. Karena keberhasilan penerapan teknologi sangat bergantung pada penerimaan oleh pengguna.

Penerimaan pengguna terhadap sistem teknologi informasi dapat didefinisikan sebagai kemauan yang muncul dalam diri pengguna untuk menerapkan sistem teknologi informasi dalam pekerjaannya. Semakin menerima sistem teknologi informasi baru, semakin besar kemauan pengguna untuk mengubah praktik penggunaan, waktu dan upaya untuk menggunakan secara signifikan sistem teknologi informasi yang baru (Pikkarainen, Pikkarainen, Karjaluoto, dan Pahnila, 2004). Cloud computing adalah kombinasi dari penggunaan teknologi komputer dengan logging berbasis internet yang merupakan pengembangan terbaru dari system client-server. Beberapa perusahaan besar sudah menerapkan cloud computing seperti Google, Zoho, Yahoo, Amazon, dan lainnya.

Google menawarkan berbagai aplikasi berbasis web, semuanya dihosting di cloud Google. Antara lain, Anda dapat menggunakan perangkat lunak pengolah kata di Google Docs, presentasi di Google Presentation, email melalui Gmail, atau kalender / penjadwalan di Google Calendar, sampai Adsense dan Adwords. Semua aplikaai yang disebutkan diatas dirangkum dalam Google Apps. Susilo dan Yasmiati (2011) menjelaskan bahwa Google Apps Education adalah rangkaian aplikasi kolaboratif yang dirancang untuk sekolah dan universitas. Tidak hanya guru atau orang tua yang dapat mengambil keuntungan dari fasilitas cloud, siswa juga dapat menggunakan cloud untuk berkolaborasi dalam tugas di sekolah mereka, misalnya untuk menyelesaikan pekerjaan rumah yang harus diselesaikan dalam kelompok dan tidak ada cara yang lebih mudah untuk berkolaborasi selain menggunakan aplikasi web.

Tugas individu bagi calon kepala sekolah merupakan tugas yang harus dilakukan secara individual sesuai dengan situasi dan keadaan sekolah dan tempat magang yang memiliki masalah dan faktor pendukung yang berbeda di antara sekolah lainnya. Sejauh mana calon kepala sekolah dapat mengusulkan solusi alternatif yang akan menjadi modal pengalaman awal ketika ditunjuk sebagai kepala sekolah. Hasil kerja terbaik pada tahap ini dapat menjadi sumber pembelajaran bagi peserta lain atau sebaliknya, sesama peserta saling membantu untuk mengusulkan solusi terbaik untuk masalah yang dihadapi melalui forum diskusi pada aplikasi Google Documents. Masalah yang ditemui dapat didiskusikan atau dieksekusi pada saat itu juga sehingga ada umpan balik pada saat yang sama, tidak hanya saling mengirim email. Google Documents menyediakan kegiatan bagi pengguna secara real time 
tidak hanya untuk melihat dokumen bersama, tetapi pengguna juga diberikan kemudahan untuk mengedit dokumen bersama pada waktu yang sama.

Teori tindakan Cogent (Theory of Reason Action) adalah teori yang menjelaskan bahwa minat seseorang untuk melakukan (atau tidak melakukan) suatu perilaku adalah penentu langsung dari tindakan atau perilaku (Jogiyanto, 2007). Teori ini disusun menggunakan asumsi dasar bahwa manusia berperilaku secara sadar dan mempertimbangkan semua informasi yang tersedia (Maria dan Widodo, 2010). Model penerimaan teknologi (Technology Acceptance Model atau TAM) merupakkan satu model penerimaan sistem teknologi informasi yang akan digunakan oleh pengguna (Jogiyanto, 2007). TAM dikembangkan berdasarkan model teori tindakan. Reaksi dan persepsi pengguna teknologi informasi akan mempengaruhi sikapnya dalam menerima teknologi informasi (Apriyanto, 2015; Wibowo, 2008). berikut ialah model TAM yang telah dikembangkan ditunjukkan pada Gambar 1.

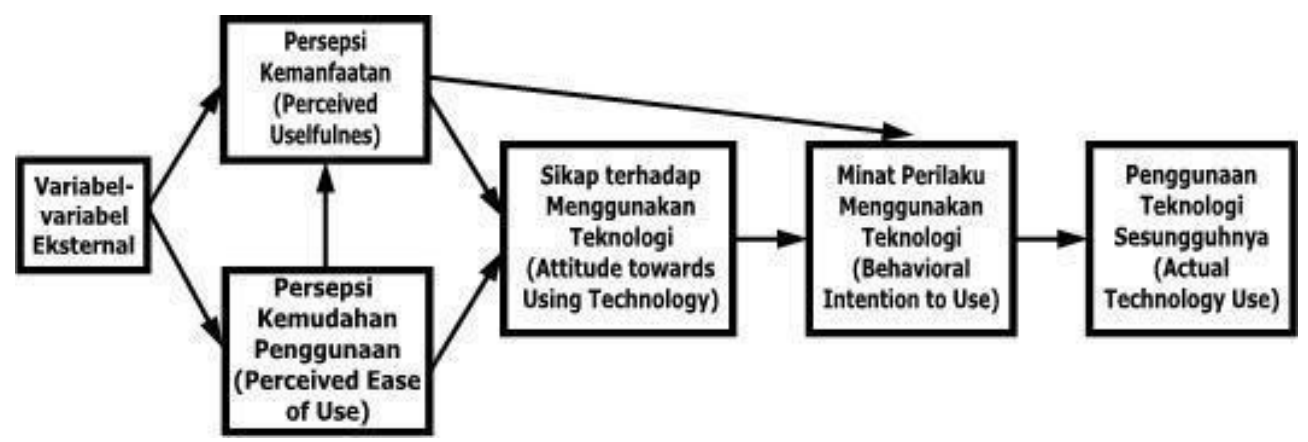

Gambar 1. Technology Acceptance Models (Jogiyanto, 2007)

Maria dan Widodo (2010) dalam studi penerimaan Adobe Photoshop menggunakan model penelitian yang telah dikembangkan, variabel eksternal yang digunakan adalah kemampuan diri terhadap komputer / Computer Self Efficacy. Model TAM yang dikembangkan dalam penelitian Mary dan Widodo (2010) ialah seperti pada Gambar 2.

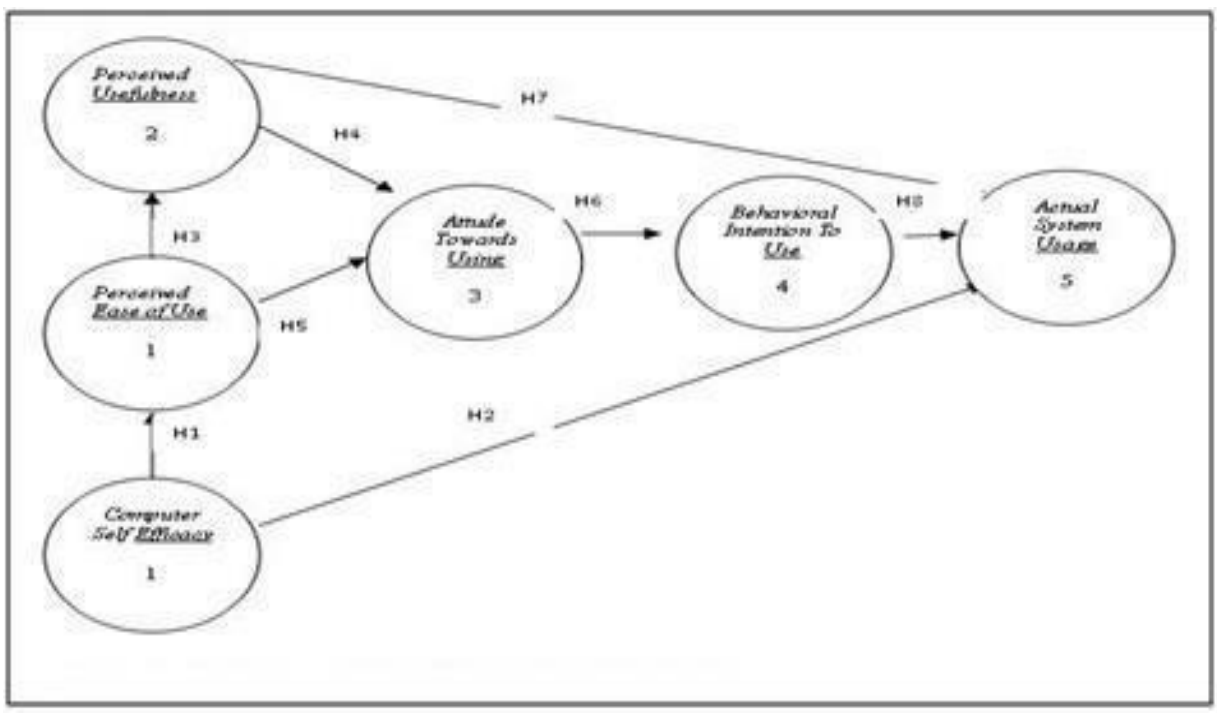

Gambar 2. Model TAM Maria dan Widodo (2010)

Walczuch, et al (2007) berpendapat bahwa "Indeks kesiapan teknologi atau technology readiness index (TRI) adalah kerangka kerja yang berkaitan dengan teknologi secara umum. TRI adalah kerangka kerja terkait teknologi secara umum, yang berarti indeks kesiapan tersebut diukur berdasarkan pada 
bagaimana teknologi tersebut digunakan oleh pengguna dan diterima. Indeks Kesiapan Teknologi bentuknya sangat beragam. Menurut penelitian Parasuraman dan Colby (2001), TRI digunakan untuk mengukur kesiapan pengguna dalam menggunakan teknologi baru dengan indikator empat variabel kepribadian: optimisme / harapan (optimism), inovasi (innovativeness), ketidaknyamanan (discomfort), dan ketidakamanan (insecurity). Walczuch, Lemmink, dan Streukens (2007) menggabungkan TAM dan TRI untuk melihat hubungan antara variabel dinatara TRI dan TAM.

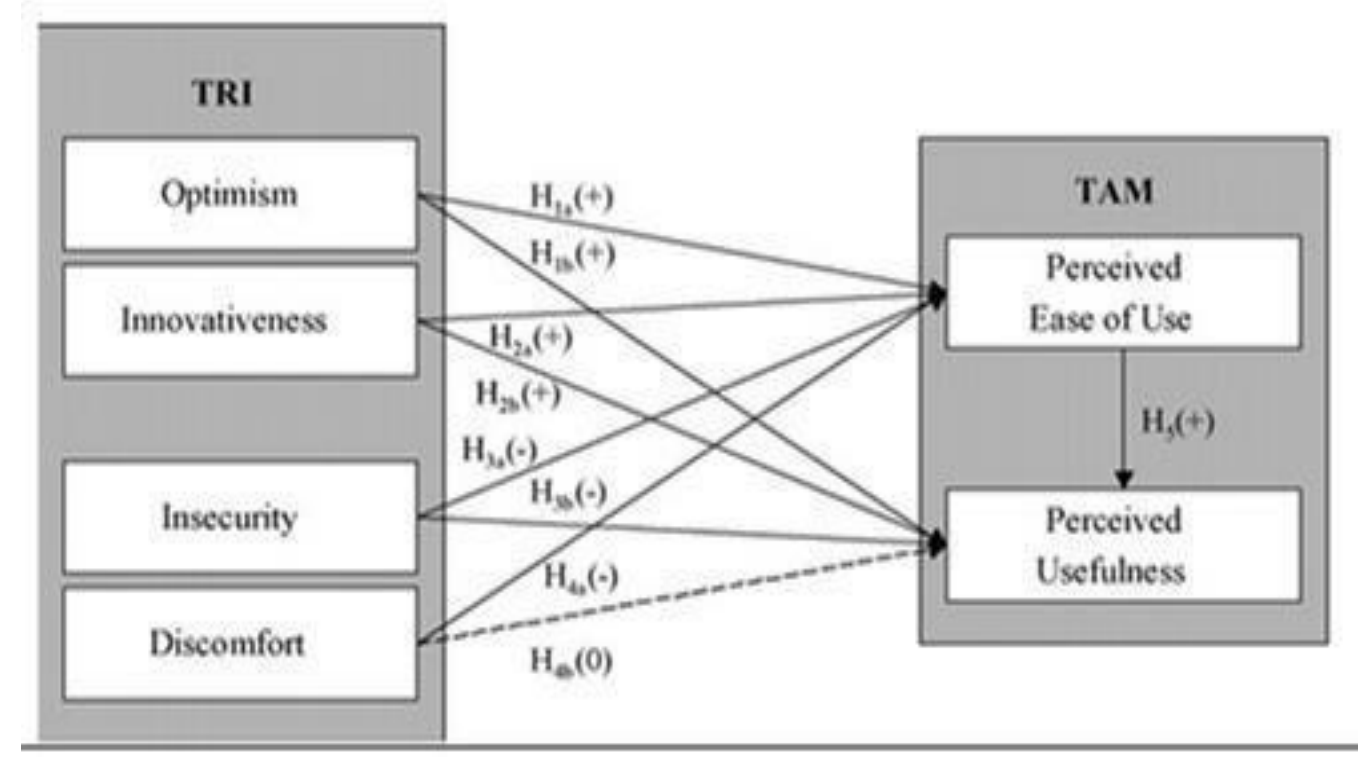

Gambar 3. Model Penelitian, Kolaborasi TRI dan TAM

Analisis Jalur (path analysis) adalah serangkaian teknik statistik yang memungkinkan pengujian sirkuit hubungan yang relatif "kompleks" secara bersamaan (Waluyo, 2011). Santoso (2011) menjelaskan bahwa ada beberapa tahapan utama yang akan dilewati untuk menggunakan analisis jalur dalam kegiatan penelitian, yaitu membuat model regresi (Spesifikasi Model), Menyiapkan desain penelitian dan pengumpulan data, Identifikasi Model dan Pengujian Model. Model Pengujian dan Estimasi Model menggunakan Perangkat lunak menggunakan SPSS versi 18. Dalam menggunakan SEM sebagai alat analisis, peneliti harus membangun model berdasarkan justifikasi teoretis atau proses penalaran yang cukup kuat sehingga analisis faktor yang berlaku dalam analisis jalur adalah Analisis Faktor Konfirmatori karena bertujuan untuk mengkonfirmasi apakah indikator digunakan dan memiliki teori dan alasan yang dapat mengkonfirmasi faktor tersebut (Waluyo, 2011).

Kerangka teoritis yang menjadi dasar pemikiran adalah modifikasi TAM yang dikembangkan oleh penelitian TAM sebelumnya (Davis, 1989) yang telah dikembangkan menggunakan faktor-faktor eksternal. Karena penelitian ini bertujuan untuk menguji seberapa siap para calon kepala sekolah menggunakan teknologi yang pada akhirnya akan mempengaruhi perilaku penerimaan mereka terhadap aplikasi teknologi Google Docs. Dalam penelitian ini faktor-faktor eksternal diambil dari penelitian TRI dan TAM (Walczuch, Lemmink, dan Streukens, 2007) menggunakan faktor-faktor eksternal yang diadaptasi dari Technology Readiness Index yang dipelajari oleh Parasuraman dan Colby (2001).

Model penelitian Walczuch, Lemmink, dan Streukens (2007) meneliti pengaruh kesiapan pada penerimaan teknologi terhadap kegunaan dan model penelitian Maria dan Widodo (2010) untuk menilai pengaruh kemampuan diri akan komputer terhadap penerimaan teknologi yang mendorong adanya penggunaan. Desain kedua model berbeda dan jumlah variabel yang digunakan, tetapi ada 2 variabel yang sama yaitu manfaat dan kemudahan. Oleh karena itu, berdasarkan pada keberadaan irisan dan semua variabel yang digunakan oleh kedua model, model penelitian Walczuch, Lemmink, dan Streukens 
(2007) dikombinasikan dengan model penelitian Maria dan Widodo, (2010) sehingga seperti gambar di bawah ini

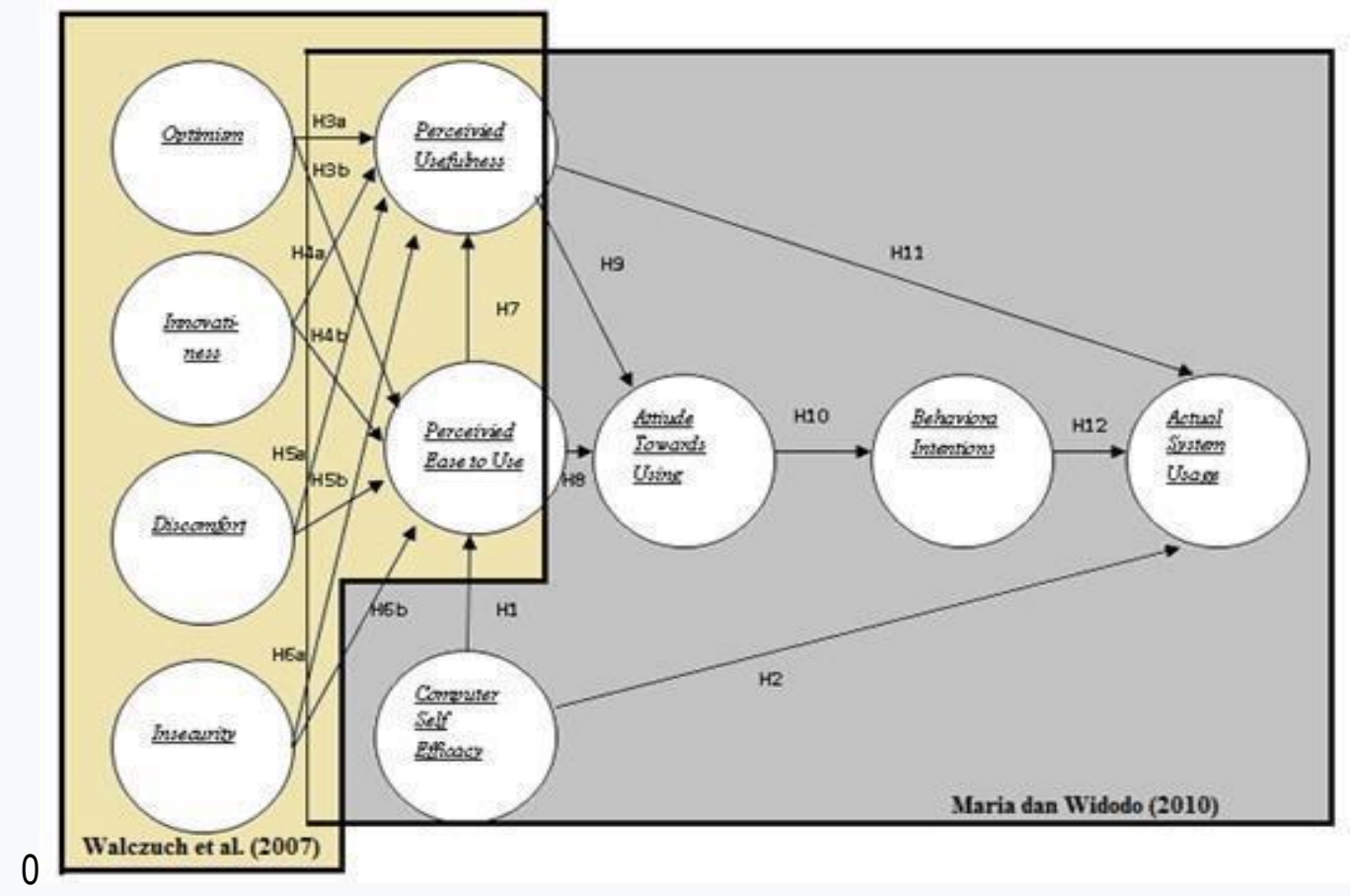

Gambar 4 Technology Acceptance Model (TAM) dalam penelitian ini

\section{METODE PENELITIAN}

Jenis penelitian yang akan dilakukan pada penelitian ini adalah kategori penelitian eksplanatori. Populasi penelitian ini berjumlah 80 calon kepala sekolah dengan sampel 40 responden. Teknik pengambilan sampel menggunakan teknik Purposive Sampling. Untuk mendapatkan data yang dibutuhkan, pengumpulan data dilakukan melalui angket pertanyaan tertutup dengan skala semantik diferensial. Teknik analisis data menggunakan analisis deskriptif (SPSS 18.0) dan analisis inferensial.

Penelitian tentang penerimaan teknologi baru sangat luas mengingat ada banyak konstruksi dan variabel eksternal yang lahir dalam perkembangannya. Oleh karena itu dalam penelitian ini peneliiti membatasi pada kesiapan dan penerimaan penggunaan teknologi aplikasi Google Docs dengan menggabungkan model TRI on TAM (Walczuch, Lemmink, dan Streukens, 2007) dan model TAM yang dikembangkan oleh Maria dan Widodo (2010). Sampel penelitian adalah peserta pelatihan calon kepala sekolah SD Ngawi pada bulan Februari-Mei 2018 di. Rumusan masalah dalam penelitian ini adalah apakah pengguna aplikasi Google Documents dalam hal ini para peserta pelatihan Kepala Sekolah Kabupaten Ngawi siap menggunakan dan menerima teknologi aplikasi ini untuk penyelesaian tugas individu pada saat pelatihan?

Hipotesis umum dalam penelitian ini adalah sebagai berikut: diduga pengguna aplikasi Google Docs dalam hal ini adalah peserta pelatihan calon kepala sekolah SD Ngawi Kabupaten telah siap menggunakan dan menerima teknologi aplikasi generasi cloud computing.

Sedangkan hipotesis khusus dalam penelitian ini adalah sebagai berikut:

1. H1: persepsi diri terhadap kemampuan komputer (Computer Self Efficacy / CSE) secara signifikan memengaruhi kemudahan menggunakan Google Docs (Perceived Ease of Use / PEOU). 
2. H2: persepsi diri terhadap komputer (Computer Self Efficacy / CSE) secara signifikan memengaruhi perilaku penggunaan aktual Google Documents (Actual System Usage / ASU).

3. H3a: Pengguna yang optimis terhadap teknologi Google Documents (Optimism / OPT) berpengaruh secara signifikan terhadap persepsi kemanfaatan Perceived Usefulness (PU).

4. H3b: pengguna optimis teknologi terhadap Google Documents (Optimism / OPT) secara signifikan memengaruhi kemudahan menggunakan Google Documents (Perceived Ease of Use / PEOU).

5. H4a: Diduga bahwa pengguna yang telah berinovasi dalam teknologi Google Documents (Innovatiness / INN) secara signifikan memengaruhi secara signifikan pengaruhnya terhadap persepsi kemanfaatan Perceived Usefulness (PU).

6. H4b: Pengguna yang yang telah berinovasi dalam teknologi Google Documents

(Innovatiness / INN) secara signifikan memengaruhi kemudahan menggunakan Google Documents (Perceived Ease of Use / PEOU).

7. H5a: Pengguna yang dicurigai yang memiliki ketidaknyamanan terhadap teknologi Google Documents (Discomfort / DIS) secara signifikan mempengaruhi pengaruh terhadap persepsi pemanfaatan (Perceived Usefulness PU).

8. H5b: Pengguna yang memiliki ketidaknyamanan total teknologi Google Documents (Discomfort / DIS) secara signifikan mempengaruhi kemudahan menggunakan Google Documents (Perceived Ease of Use / PEOU).

9. H6a: Pengguna yang memiliki rasa tidak aman tentang teknologi Google Documents (Insecurity / INS) secara signifikan mempengaruhi persepsi kemanfaatan (Perceived Usefulness / PU).

10. H6b: Pengguna yang memiliki rasa tidak aman tentang teknologi Google Documents (Insecurity / INS) secara signifikan mempengaruhi pengaruh kemudahan penggunaan affect the ease of use (PEEP).

11. H7: persepsi kemudahan menggunakan Google Docs (Perceived Ease of Use / PEOU) secara signifikan memengaruhi persepsi kemanfaatan (Perceived Usefulness / PU.

12. H8: Diduga persepsi kemudahan menggunakan Google Docs (Perceived Ease of Use / PEOU) secara signifikan mempengaruhi sikap pengguna (Attitude Toward Using / ATU).

13. H9: Diduga persepsi tentang manfaat Google Docs (Perceived Usefulness / PU) secara signifikan mempengaruhi sikap pengguna (Attitude Toward Using / ATU).

14. H10: Sikap pengguna yang diduga Google Documents (Attitude Toward Using / ATU) secara signifikan memengaruhi perilaku pengguna (Behavioral Intention to Use / BITU).

15. H11: Dugaan persepsi manfaat Google Documents (Perceived Usefulness / PU) secara signifikan memengaruhi penggunaan aktual (Actual System Usage / ASU).

16. H12: niat pengguna Google Documents (BehavioralBehavioral Intention to Use / BITU) secara signifikan mempengaruhi penggunaan aktual (Actual System Usage / ASU).

\section{HASIL DAN PEMBAHASAN}

Data memiliki standar deviasi minimum 0,870 dan maksimum 1,3486. Dan nilai cr pada skewness dan kurtosis dalam kisaran nilai yang disarankan adalah $-2,4758$ hingga 2,58. Teori berbasis model yang menjadi model awal penelitian ini digambarkan pada Gambar 5. 


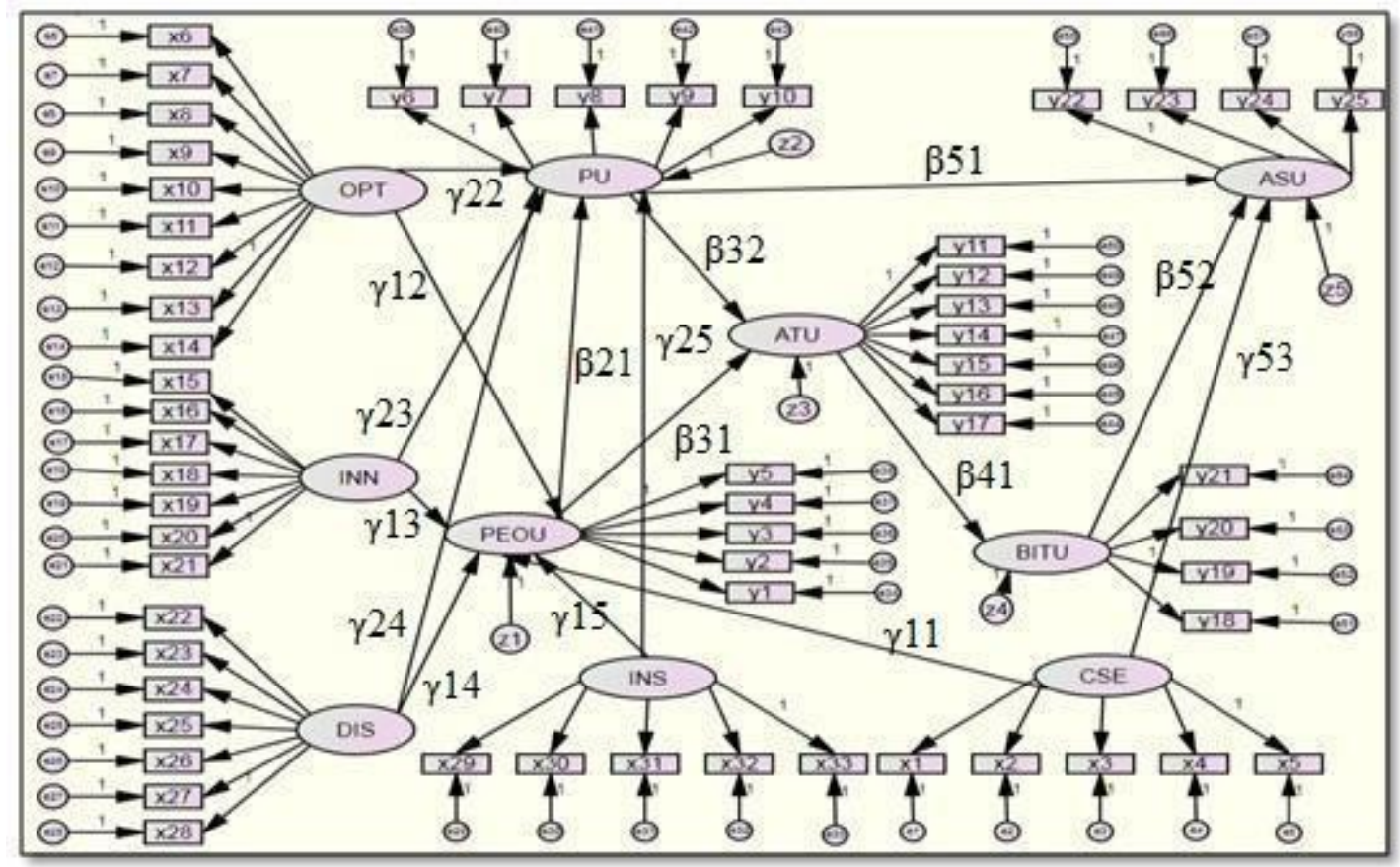

Gambar 5. Model Hipotesis Awal Penelitian

Untuk mengukur validitas konstruk dapat dilihat dari nilai loading factor yang merupakan nilai regresi standar. Tes dilakukan dengan model analisis Confirmatory Factor Analysis (CFA) dari konstruksi eksogen dan endogen. Indikator dikatakan valid jika memuat faktor> 0,50.

Table 1. Validitas Hasil (CFA)

\begin{tabular}{ll}
\hline Konstruk & Deskripsi \\
\hline Computer self efficacy (CSE) & Indikator x1 invalid dan dihilangkan dari model \\
\hline Optimistic (OPT) & Semua indikator valid \\
\hline Innovation (INN) & indikator x16 invalid dan dihilangkan dari Model \\
\hline Discomfort (DIS) & Indikator x27 dan x26 invalid dan dihapus dari model \\
\hline Insecurity (INS) & Indicator x31 dan x32 invalid dan dihapus dari model \\
\hline Perceived of Ease (PEOU) & Semua indikator valid \\
\hline Perceived of Utilization (PU) & Semua indikator valid \\
\hline attitudes (ATU) & Semua indikator valid \\
\hline Usage intent behavior (BITU) & Indikator y21 invalid dan dihapus dari model \\
\hline Real usage (ASU) & Semua indikator valid \\
\hline
\end{tabular}

Hasil uji reliabilitas sedang, hampir semua konstruk memenuhi nilai cut-off untuk keandalan konstruk yang memiliki nilai> 0,70, sehingga dapat dikatakan bahwa hampir setiap konstruk memiliki reliabilitas yang baik.

Hasil model uji kesesuaian diketahui bahwa probabilitas nilai lebih kecil dari nilai yang disarankan, yaitu kurang dari 0,05 . Ini berarti teori model yang diusulkan dalam studi ini tidak cocok dengan model 
populasi yang diamati. Berdasarkan hasil uji fit model dapat dikatakan model tidak fit oleh karena itu langkah selanjutnya adalah membuat diagram jalur model (path diagram) atau model jalur awal.

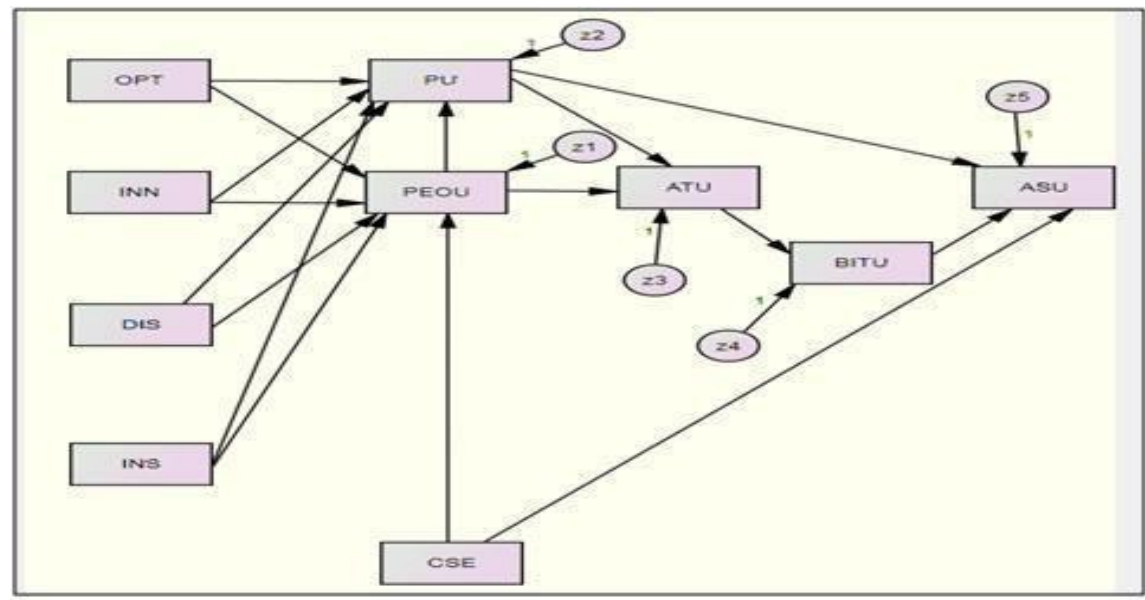

Gambar 6. Model Penelitian Garis Awal

Hasil uji signifikansi dalam diagram jalur model penelitian yang dijelaskan Tabel 2.

Tabel 2. Tes Signifikansi Model Garis Awal

\begin{tabular}{|c|c|c|c|c|c|}
\hline & & & Koefisien Regresi & $\mathbf{P}$ & Deskripsi hubungan \\
\hline PEOU & <--- & OPT & 0.147 & 0.008 & Signifikan \\
\hline PEOU & $<--$ & INN & 0239 & $\star \star \star \star$ & Signifikan \\
\hline PEOU & $<---$ & DIS- & 0.052 & 0.558 & Tidak signifikan \\
\hline PEOU & <--- & INS & 0.005 & 0.971 & Tidak Signifikan \\
\hline PEOU & <--- & CSE & 0.407 & $* * *$ & Signifikan \\
\hline PU & $<---$ & OPT & 0.093 & 0.016 & Signifikan \\
\hline PU & <--- & INN & 0.092 & 0.065 & Tidak Signifikan \\
\hline PU & $<--$ & DIS & -0.072 & 0.240 & Tidak Signifikan \\
\hline PU & <--- & INS & 0.050 & 0.581 & tidak Signifikan \\
\hline PU & $<--$ & PEOU & 0.615 & $* * \star$ & Signifikan \\
\hline ATU & $<--$ & PU & 0.900 & $* * *$ & Signifikan \\
\hline ATU & $<--$ & PEOU & 0.341 & $\star * \star$ & Signifikan \\
\hline BITU & <--- & ATU & 0.391 & $* * *$ & Signifikan \\
\hline ASU & $<--$ & PU & 0.282 & $* * *$ & Signifikan \\
\hline ASU & $<--$ & BITU & 0404 & 0.001 & Signifikan \\
\hline ASU & <--- & CSE & 0.239 & 0.003 & Signifikan \\
\hline
\end{tabular}


Dari tabel 2 maka model jalur akhir terbentuk, di mana jalur tidak signifikan $(P>0,05)$ harus dihapus dan pada bagian ini hipotesis khusus dijawab melalui model penelitian akhir pada gambar 7 berdasarkan uji signifikan hasil dari model jalur akhir pada tabel 3 adalah signifikan di setiap jalur.

Tabel 3. Hasil Akhir Model Uji Signifikan

\begin{tabular}{|l|l|l|l|l|}
\hline \multicolumn{3}{|c|}{ Relation Causal } & Coefficient Regression & \multicolumn{1}{c|}{ P } \\
\hline PEOU & $<---$ & OPT & 0.148 & 0.007 \\
\hline PEOU & $<---$ & INN & 0.219 & 0.002 \\
\hline PEOU & $<---$ & CSE & 0.406 & ${ }^{* *}$ \\
\hline PU & $<---$ & OPT & 0.116 & 0.003 \\
\hline PU & $<---$ & PEOU & 0.638 & ${ }^{* *}$ \\
\hline ATU & $<---$ & PU & 0.900 & $* * *$ \\
\hline ATU & $<---$ & PEOU & 0.341 & $* * *$ \\
\hline BITU & $<---$ & ATU & 0.391 & $* *$ \\
\hline ASU & $<---$ & PU & 0.282 & $* * *$ \\
\hline ASU & $<---$ & BITU & 0404 & 0001 \\
\hline ASU & $<---$ & CSE & 0.239 & 0.003 \\
\hline
\end{tabular}

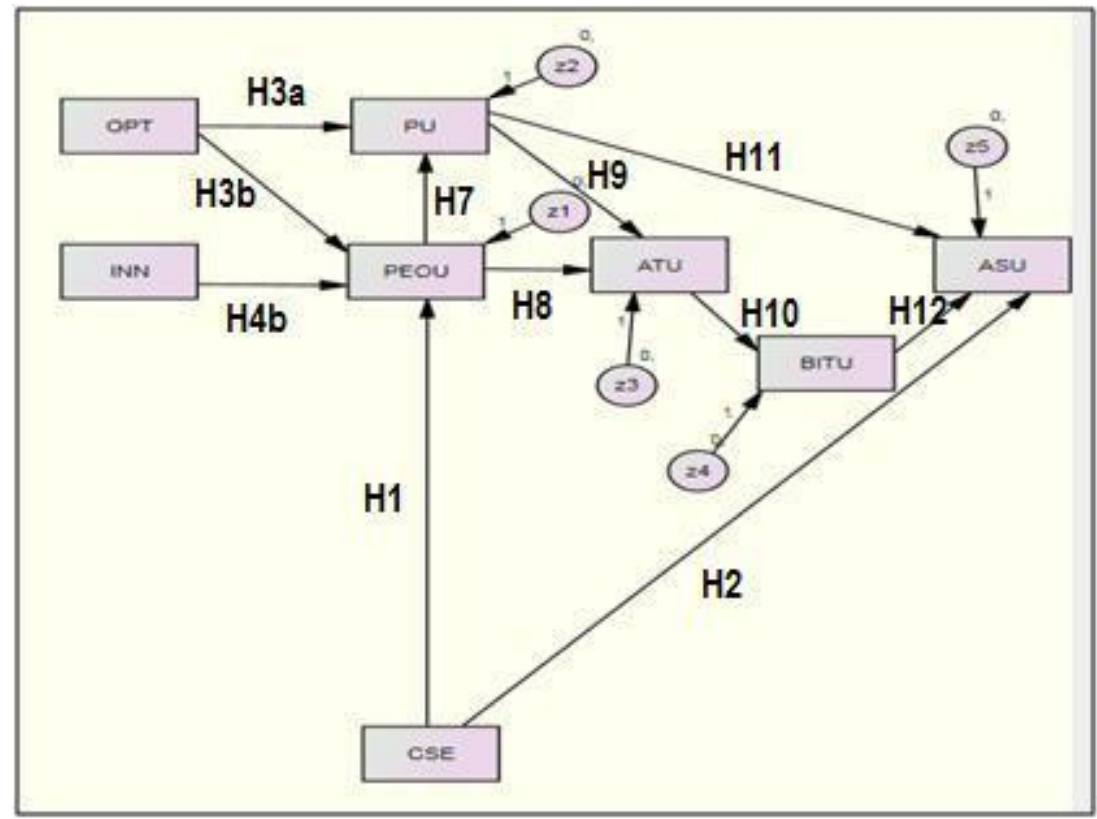

Gambar 7 Model Penelitian Akhir

Berdasarkan hasil pengujian signifikansi yang telah dilakukan, dapat dikatakan bahwa variabel yang dirasa mudah untuk menggunakan aplikasi Google Documents (PEOU) dalam penelitian ini mempengaruhi kemampuan (CSE) dan dua variabel kesiapan teknologi yaitu optimis (OPT) dan inovasi (INN) yang dimiliki oleh calon kepala sekolah terhadap teknologi cukup tinggi.

Variabel persepsi manfaat (PU) dipengaruhi bersama oleh optimisme (OPT) dan persepsi untuk menggunakan teknologi aplikasi Google Docs (PEOU). Namun, inovasi pengguna (INN) tidak memiliki 
pengaruh pada persepsi manfaat (PU) untuk menggunakan teknologi aplikasi Google Documents, ini dimungkinkan karena para calon kepala sekolah tersebut lebih cenderung melihat kemudahan (PEOU) aplikasi, terutama dalam menyelesaikan tugas On The Job Learning.

Sikap (ATU) dipengaruhi bersama oleh persepsi kenyamanan (PEOU) dan persepsi kegunaan (PU) ketika menggunakan teknologi aplikasi Google Docs. Sedangkan perilaku niat penggunaan (BITU) dipengaruhi oleh sikap penggunaan (ATU) terhadap teknologi aplikasi Google Documents, sehingga jika ATU meningkat maka BITU meningkat.

Penggunaan aktual (ASU) dipengaruhi bersama oleh kemampuan menggunakan komputer (CSE), intensi (BITU) dan Persepsi Pemanfaatan (PU), sehingga dapat diartikan bahwa kemampuan komputer yang sudah dimiliki, perilaku niat untuk menggunakan teknologi dan kegunaan yang dirasakan pengguna sangat mempengaruhi penggunaan aplikasi Google Documents.

Jadi berdasarkan model akhir penelitian ini dapat dikatakan bahwa penerimaan teknologi mempengaruhi kesiapan pengguna dalam menggunakan teknologi walaupun tidak semua variabel kesiapan (TRI) mempengaruhi penerimaan teknologi (TAM). Dan calon kepala sekolah kabupaten ngawi dapat dikatakan cukup siap dan menerima teknologi aplikasi Google Documents untuk penyelesaian tugas individu ataupun kelompok.

\section{KESIMPULAN}

Calon kepala sekolah yang cukup siap dan menerima teknologi aplikasi Google Docs untuk digunakan untuk menyelesaikan tugas individu dijelaskan melalui hubungan sebab akibat dari kesiapan teknologi untuk penerimaan teknologi aplikasi adalah sebagai berikut:

1) Variabel optimis / OPT yang merupakan salah satu indeks kesiapan teknologi berpengaruh signifikan terhadap kemudahan penggunaan / PEOU dan manfaat / PU yang merupakan variabel penerimaan teknologi.

2) Variabel inovasi / INN yang merupakan salah satu indeks kesiapan teknologi secara signifikan mempengaruhi kemudahan penggunaan / PU.

3) Variabel kemudahan penggunaan / PEOU yang mempengaruhi kemampuan komputer / pengaruh CSE untuk mengeksploitasi / PU, di mana keduanya juga mempengaruhi sikap penggunaan / ATU.

4) Variabel niat penggunaan / BITU mempengaruhi sikap penggunaan / ATU.

5) Variabel manfaat / PU dan kemampuan mandiri ke komputer / CSE dan perilaku niat penggunaan / BITU berpengaruh signifikan terhadap penggunaan nyata / ASU.

\section{SARAN}

Jadi berdasarkan kesimpulan yang dijelaskan sebelumnya, peneliti menyarankan semua sekolah menyediakan infrastruktur optimal untuk mendukung penggunaan Aplikasi Google Documents di sekolah. Karena ada kemungkinan bahwa faktor lingkungan cukup besar pada penerimaan teknologi, lebih baik bagi setiap kandidat untuk mempraktikkan tugas menetapkan tugas individu menggunakan aplikasi Google Documents kepada sekolah guru atau siswa sehingga warga sekolah tidak hanya mendapatkan teknologi dalam teori tetapi juga digunakan untuk berlatih. Penyelenggaraan pelatihan untuk semua guru tidak hanya Teknologi Informasi dan Komunikasi / guru TIK untuk menggunakan aplikasi Google Docs yang sebenarnya juga bermanfaat untuk penyelesaian pekerjaan guru tidak hanya calon kepala sekolah. 
Perlu adanya Pelatihan penggunaan perangkat keras dan lunak komputer serta konseling penggunaan perangkat komputer yang sehat dan aman.Hasil penelitian ini dapat dikembangkan dalam berbagai studi lanjutan yang lebih luas, seperti penambahan moderasi untuk mengetahui tingkat keanekaragaman, faktor eksternal yang lebih luas yang mungkin untuk dikembangkan lagi dengan model atau pendekatan lain yang masih relevan dengan kasus ini.

\section{DAFTAR PUSTAKA}

Apriyanto. (2015). Kajian Penerimaan Sistem Informasi Kepesertaan dengan Pendekatan Technology Acceptance Model Studi Kasus pada Dana Pensiun PLN. Jurnal Pilar Nusa Mandiri, 11(1), 30-42 Jogiyanto. (2007). Sistem Informasi Keperilakuan. Yogyakarta: Andi Publisher.

Maria, S., \& Widodo, P.P (2010). Kajian Penggunaan Adobe Photoshop Berdasarkan Pendekatan TAM: Studi Kasus Pada SMK Negeri 5 Tangerang. Jakarta: STMIK Nusa Mandiri.

Parasuraman, A. \& Colby, C.L (2001). Techno-Ready Marketing: How and Why Your Customers Adopt Technology. New York: Free Press,

Pikkarainen, T., Pikkarainen, K., Karjaluoto, H., \& Pahnila, S. (2004). Consumer Acceptance of Online Banking: An Extension of The Technology Acceptance Model. Internet Research, 14(3), 224-235.

Santoso, S. (2011). Structural Equation Modeling (SEM): Konsep \& Aplikasi dengan AMOS 18. Jakarta: Elex Media Komputindo.

Susilo, A., \& Yasmiati. (2011). Google Apps for Learning Processes at the Faculty of Information Technology (FTI). Yogyakarta: Universitas Respati Indonesia.

Walczuch, R., Lemmink, J., \& Streukens, S. (2007). The Effect of Service Employees' Technology Readness on Technology Acceptance. Information \& Management, 44, 206-215.

Waluyo, M. (2011). Panduan dan Aplikasi Structural Equation Modelling (Untuk Aplikasi Model Dalam Penelitian Teknik Industri, Psikologi, Sosial, dan Manajemen). Jakarta Barat: Penerbit Indeks.

Wibowo, A. (2008). Kajian Tentang Perilaku Pengguna Sistem Informasi Dalam Pendekatan Technology Acceptance Model (TAM). Program Studi Sistem Informasi Fakultas Teknologi Informasi Universitas Budi Luhur. 